\title{
Adaptation science and policy in China's agricultural sector
}

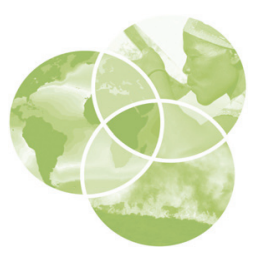

Sarah Rogers*

Edited by, Maria Carmen Lemos, Domain Editor, and Mike Hulme, Editor-in-Chief

In recent years, China's central government has begun to articulate its adaptation policy and to identify measures to adapt the nation's agriculture to changing precipitation patterns, higher temperatures, and extreme events. These developments are occurring at a time when the agricultural sector is in flux: while the major grain crops-rice, wheat, and corn-are still central to food security, many smallholder farmers have shifted away from land-intensive production to growing higher-value, labour-intensive horticultural products, such as fruit and vegetables. In addition, new forms of agriculture are emerging because of out-migration and land transfers. This review introduces the adaptation policy context for agricultural adaptation in China and reviews existing research on impacts and adaptation. It then discusses how well existing research and policy actually reflect the challenges of adapting China's farms to climate change. Four issues are discussed which together suggest that current science and policy very poorly reflect challenges on the ground: the framing of agriculture as a relatively homogeneous sector; the absence of any vulnerability assessments attuned to local contexts; a bias toward large-scale engineering solutions; and insufficient consideration of local government capacity. ๑ 2016 Wiley Periodicals, Inc.

How to cite this article:

WIREs Clim Change 2016. doi: 10.1002/wcc.414

\section{INTRODUCTION}

*Correspondence to: rogerssm@unimelb.edu.au

Centre for Contemporary Chinese Studies, University of Melbourne, Melbourne, Australia

Conflict of interest: The author has declared no conflicts of interest for this article. climate change is just one additional stress on livelihoods that in the past three decades have seen rapid socio-economic and environmental change. Many of these farmers live on the economic and environmental margins, despite being major producers of the products that an increasingly urbanised and wealthy population demands. Beyond their autonomous actions to protect their livelihoods, these farmers will require significant government support to successfully adapt. But farming in China is changing, particularly in wealthier coastal provinces: scholars and practitioners must also consider what adaptation means for the larger-scale new agricultural actors that are emerging.

In the past few years, China's adaptation policy has begun to take shape, but to date, there has been very little analysis of this emerging framework and what it tells us about China's ability to successfully adapt. Nor has there been an assessment of how well research is supporting this endeavour. This review is 


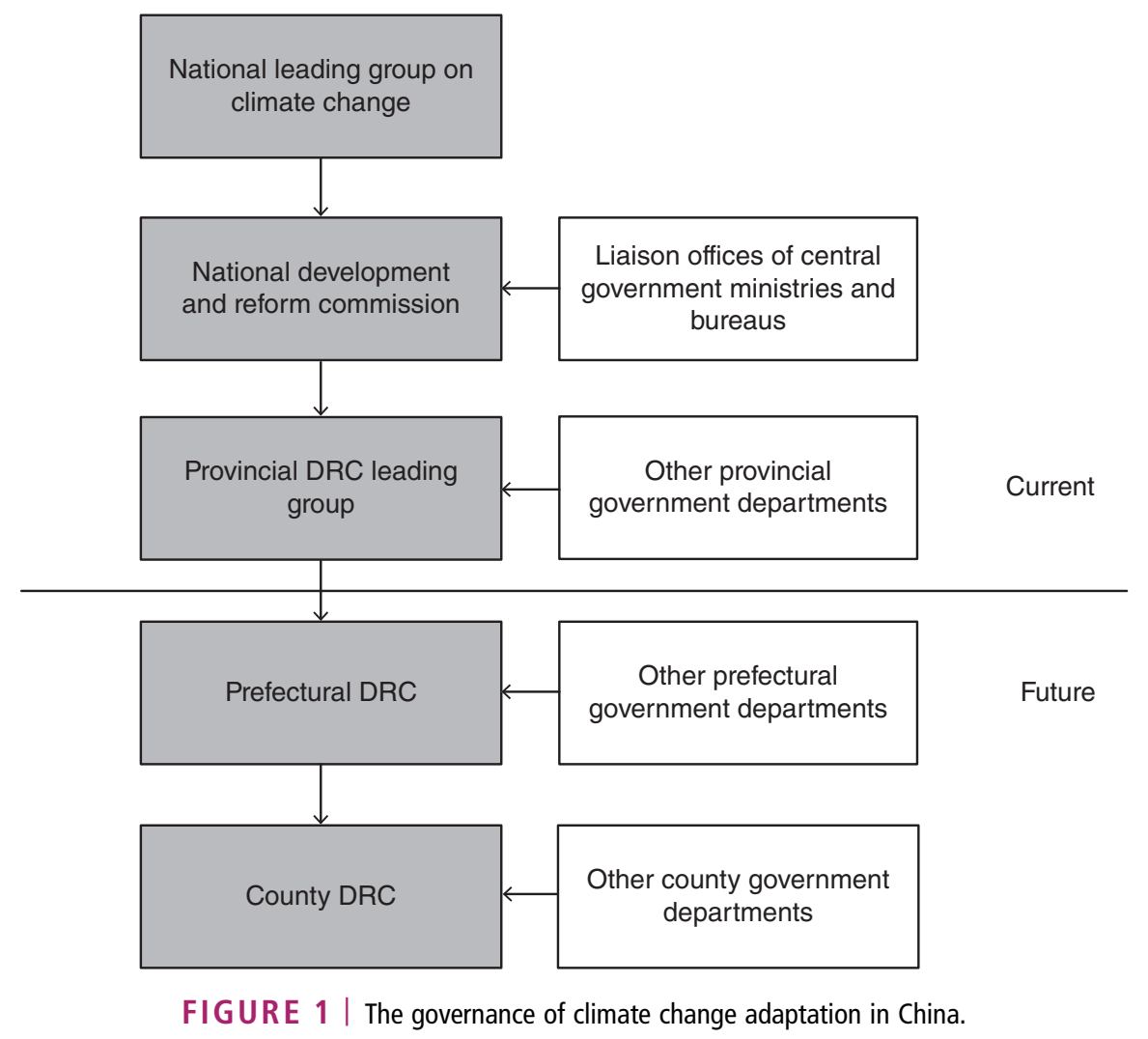

an attempt to address this gap. It asks how well does current science and policy reflect the challenges of adapting China's farms to climate change, grounding this analysis in a discussion of China's changing agricultural sector. It is organised into three main parts. The first part reviews both relevant policies for agricultural adaptation to climate change and existing research on impacts, vulnerability, and adaptation. The second part introduces some of the major changes in China's agricultural sector relevant to climate change adaptation. The third part discusses four issues that point to significant limitations in current science and policy: the framing of agriculture as a relatively homogenous sector; a bias toward largescale engineering solutions; the absence of comprehensive vulnerability assessments attuned to local contexts; and a lack of attention to local government capacity.

\section{REVIEW}

\section{Adaptation Policy in China}

While originally placed under the mandate of China's Meteorological Administration, in 1998 responsibility for climate change policy was transferred to the National Development and Reform
Commission (NDRC), a powerful body in China's central government. ${ }^{2}$ The NDRC's Department of Climate Change is responsible for analysing the impacts of climate change and for policy coordination, under the leadership of the National Leading Group Dealing with Climate Change, a high-level coordination mechanism comprised of various ministers and the premier of the State Council. Each central government ministry has liaison offices to coordinate climate change work with the NDRC, and each province has a climate change leading group within the provincial Development and Reform Commission, mirroring central government arrangements (see Figure 1). ${ }^{3}$

The NDRC has produced a number of major reports and policies relevant to adaptation. Its Initial National Communication on Climate Change to the UNFCCC in 2004 focused on sectoral impact assessments for water, agriculture, terrestrial ecosystems, and the coastal zone. ${ }^{4}$ For agriculture, the focus was on changes to the yield of major grain crops (corn, wheat, and rice), as well as cotton, and includes a brief discussion of implications for pesticide and fertiliser use. China's Second National Communication (2012) has a longer section on climate impacts and adaptation that considers impacts on cropping systems, agricultural diseases and pests, and the impacts 
of extreme events. ${ }^{1}$ The vulnerability of agricultural systems is again framed in terms of grain production and as a percentage of grain yield reductions. The adaptive strategies identified for agriculture in these earlier documents include soil fertility engineering, increased water supply and other agricultural infrastructure building, water efficiency measures, adjusting cropping patterns, and the promotion of highyield and other improved varieties. Little detail is provided on whether different agricultural or climatic regions may require different adaptation strategies, and institutional responsibilities are not specified.

Since 2008, the NDRC has also published an annual White Paper outlining China's mitigation and adaptation policies and measures. Policies and measures relevant to agricultural adaptation include expansion of irrigation capacity, promotion of high quality seed varieties, and promotion of water-saving technologies (including plastic film mulching and demand irrigation). ${ }^{5,6}$ According to the latest White Paper, 1 billion RMB-has been allocated to support dryland water-saving agriculture in north, northeast, and northwest China, which includes the establishment of 600 soil moisture and drought monitoring stations. ${ }^{6}$ No detail is provided on who has responsibility for these actions or where initial demonstration activities are being carried out. Elsewhere, the National Climate Change Plan (2014-2020) encompasses mitigation and adaptation efforts but actually says very little about adaptation. ${ }^{7}$ China's 2015 Intended Nationally Determined Contribution again stresses construction of water conservation facilities, water-saving irrigation, cultivation of heat-resistant and drought-resistant crops, and strengthened early warning systems and disaster response, but does not discuss adaptation in detail. ${ }^{8}$

China's first national-level policy specific to climate change adaptation-the National Climate Change Adaptation Strategy-was released in late 2013. It outlines similar strategies for agriculture to previous documents such as soil fertility improvements, water-saving irrigation, changes to cropping boundaries, and the use of heat and droughttolerant crop varieties. ${ }^{9}$ There are also brief mentions of increasing village disaster-preparedness, exploring agricultural disaster insurance, and establishing an early warning disaster system for agriculture. There are a number of new developments in this strategy. First, it outlines a set of guiding principles, one of which is 'highlighting the priorities' (the others are 'proactive adaptation,' 'rational adaptation,' 'collaborative cooperation,' and 'extensive participation'): based on a comprehensive analysis of climate change impacts and damages, vulnerable areas, and vulnerable populations will be prioritised for adaptation actions. ${ }^{9}$ Second, the report divides the country into three adaptation regions, each with different priorities: urbanised areas, agricultural areas, and ecological areas. One of these ecological zones is the Loess Plateau, where tasks include control of erosion, continuing implementation of Grain for Green (see Box 1), building dams, land terracing, and resettlement. Despite these developments, there is still very little detail on practical implementation: how will priority areas or populations be identified, how will sites for adaptation projects be selected, and how extensively will certain activities be implemented? It is also unclear which tasks will be prioritised if an agricultural area lies in a designated ecological zone.

As an example of provincial-level activities, Shanxi Province includes adaptation measures in its provincial-level climate change policy response. ${ }^{12}$ Specific measures in relation to agriculture reflect those identified by the central government such as accelerating the construction of water conservancy projects, increasing agricultural water use efficiency, and increasing rainwater collection capacity in watershort and hilly areas. Other objectives include increasing agricultural adaptive capacity through

BOX 1

\section{GRAIN FOR GREEN}

Introduced in 1999, the Grain for Green program (in Chinese 退耕还林 tuigeng huanlin) converts sloping farmland of a gradient exceeding $25^{\circ}$ to tree plantations or grass land, providing compensation to farmers in the form of first grain, and now direct cash transfers. Grain for Green has affected between 40 and 60 million rural households and set aside approximately 15 million hectares of farmland. ${ }^{10}$ While the program is coming to an end, another phase is highly likely, given that a third of farmers intend to reclaim converted land for cultivation if payments cease. ${ }^{11}$ Grain for Green has significant implications for agricultural adaptation: it reduces the amount of land available for cultivation and affects labour allocation (it was intended to encourage off-farm income generation), and it may also affect water availability at the local scale; none of which have been examined in any detail. The impacts of Grain for Green in a changing climate are a fertile area for future research. 
1 optimising the spatial composition of agriculture, 2 exploring new seed varieties, and building drought, flood, and disease resistance. The document suggests that further local-level policies and plans will be developed. Again, details on specific projects, their location and their funding are not available. The document does not specify how adaptation will be governed, but it is reasonable to assume that adaptation will be mainstreamed into rural development, water management, poverty alleviation, forestry, and agricultural development projects at the local level, with the local Development and Reform Commission as the coordinating body.

In terms of adaptation practice, there have been a number of collaborative adaptation programs in China, including the Impacts of Climate Change on Chinese Agriculture project (2001-2008), a partnership between the UK Department for International Development (DFID), UK Department for Energy and Climate Change (DECC) and China's Ministry of Science and Technology; and the Adapting to Climate Change in China project (DFID, DECC, Swiss Agency for Development and Cooperation, NDRC) (2009-2013). The latter worked with the provinces of Ningxia, Inner Mongolia, and Guangdong to develop climate models and simulations, assess the vulnerability of key sectors and undertake awareness and capacity building activities. These are broadscale, sector-based activities, with a focus on rice, wheat, and corn production. ${ }^{13}$ The Global Environment Facility is also funding two demonstration projects in Anhui and Henan Provinces under the Climate Smart Staple Crop Production Project (2015-2019), which will promote low-emissions technologies, carbon sequestration technology, and disease prevention and control. ${ }^{14}$ The project supports rice, wheat, and corn production.

To summarise, China's adaptation policy is still evolving, with an incomplete administrative structure and few documented examples of implementation and mainstreaming. While priorities for different regions are beginning to be identified, China's adaptation policy framework remains high-level, sectorbased, and focused heavily on the major grain crops. From current policies, we can ascertain the kinds of strategies that will likely be prioritised for agricultural adaptation. These include: water supply measures (dam building, expanding irrigation capacity, rainwater collection), water efficiency measures (plastic film mulching, demand irrigation, soil moisture monitoring), changes to crop varieties and cropping boundaries, disaster preparedness (early warning systems, disaster insurance), land improvements (terracing, soil fertility, Grain for Green), and resettlement.
While current policy covers a large range of adaptation measures, it is as yet unformed on the details of implementation, and remains focused on the major grain crops. Does research relevant to agricultural adaptation fill any of these gaps? The next section reviews the literature on impacts, vulnerability, adaptive capacity, and adaptation as they relate to agriculture. It should be noted that this is an English-language review only; it does not include the Chinese-language literature.

\section{Existing Research}

There is a large collection of studies examining climate change impacts on China's crops, particularly how higher temperatures, changing precipitation patterns, and elevated $\mathrm{CO}_{2}$ levels will affect yield and shape irrigation demand. ${ }^{15-37}$ Projections of crop productivity under various regional and global climate change models often reach conflicting conclusions. A number of studies project yield reductions without $\mathrm{CO}_{2}$ fertilization effect, and yield increases with $\mathrm{CO}_{2}$ fertilization. ${ }^{35,36}$ Some suggest positive effects such as the northward expansion of winter wheat and rice planting, ${ }^{21,23,28}$ while others find an increased likelihood of crop failure for wheat, and in some parts of the country, declines in corn productivity. ${ }^{27,34} \mathrm{~A}$ comprehensive review of existing modelling of rice and corn yield can be found in Wang et al. ${ }^{29}$ While most of these studies focus on irrigated agriculture, one study suggests that warming will be beneficial in irrigated systems, but harmful in rainfed systems. $^{28}$

There are some attempts to integrate adaptation scenarios for the agricultural sector with regional climate models and socio-economic scenarios to better understand the impacts of climate change $^{20,38}$ and to assess implications for food security. ${ }^{39}$ Results suggest that without adaptation, per capita production is likely to decrease. ${ }^{38}$ In terms of food security, modelling suggests that climate change has only a moderate (positive) effect on food security compared with other factors such as farming area and population growth. ${ }^{39}$ There is a lack of detailed analysis of how crop productivity and climate impacts will interact with changing agricultural water availability as urban and industrial demand continues to grow.

In large part, the studies listed above reflect the policy focus on rice, wheat, and corn. Only a handful of studies include other crops such as canola, potato, or soybean production. ${ }^{18,34,40}$ There are no detailed studies of climate change impacts on vegetable or fruit production. In fact, some studies are based on 
county crop statistics from the $1990 \mathrm{~s},{ }^{34}$ failing to take into account two decades of diversification and specialization (discussed further below). Existing research also reflects the broad scales at which adaptation policy operates: most studies consider impacts at national or regional scales, with often limited relevance to adaptation at the local scale. Only recently have studies began to emerge specific to particular provinces, for instance Gansu Province, ${ }^{40}$ or specific to particular land types, such as low-lying land affected by salinity in Jiangsu Province. ${ }^{41}$ There are also a handful of studies examining the economic impacts of climate change in terms of agricultural prices, agricultural net revenue, trade, food self-sufficiency, and farmers' incomes. ${ }^{42-46}$

To better understand the interaction of biophysical and socio-economic factors, it is also important to consider studies of vulnerability, adaptive capacity, and adaptation in agricultural contexts. One such study quantitatively assessed the vulnerability of agriculture to climate change at a regional scale for two time periods (2010s and 2040s). ${ }^{47}$ This study identifies hot spots in southern China's Yunnan, Guizhou, and Guangxi provinces, but is not attuned to different cropping systems. Elsewhere, grain production in the Loess Plateau region is identified as particularly vulnerable given observed warming. ${ }^{18}$ Other quantitative assessments consider vulnerability of a single crop in a single location. ${ }^{48}$

More in-depth, qualitative studies of vulnerability, typically drawing on a rural livelihoods approach, tell us much more about the nature of vulnerability in rural China: they describe how adaptive capacity can change over time, how differences in cropping patterns and socio-economic conditions shape sensitivity and vulnerability, and they discuss the relationship between crop diversification and adaptive capacity. ${ }^{49-53}$ Liu et al. ${ }^{51}$ explore differential vulnerability between and within villages in irrigated villages in Shandong where farmers were coping with low flows in the Yellow River Basin, and to some extent the role that local institutions play in creating different sets of entitlements. Knutsson and Ostwald $^{53}$ describe how poorer groups within the village are more vulnerable because of a lack of assets or lack of flexibility in assets. In Yunnan Province, Zheng et al. ${ }^{49}$ and $\mathrm{Su}$ et al. ${ }^{50}$ conclude that greater diversity in crop production or diversification into off-farm activities can buffer households from climatic stress. The latter argues that the biasing of extension services toward cash crop production does not facilitate diversification as a coping strategy. ${ }^{50}$ Another study in Yunnan Province highlights the risks of replacing diversified livelihoods with specialised rubber production, as encouraged by local authorities. ${ }^{52}$ In Shaanxi Province, Hageback et al. ${ }^{54}$ make the point that economic forces, not climate change, are the primary drivers of land use change and coping strategies, as do $\mathrm{Li}$ et al. $^{55}$ in Tibet. Finally, a study in Shanxi Province highlights the role of financial and natural capital in driving greater vulnerability of resettled households compared with non-resettled households. ${ }^{56}$

Other studies focus not on vulnerability but on farmers' decision-making in response to various climatic stressors (those that consider adaptation in pastoral and agro-pastoral communities ${ }^{57-61}$ are not considered further here), and also local government policies to support farmers' adaptation. In their study of six provinces, Chen et al. $^{62}$ found that most farming households were undertaking adaptation activities in response to drought, particularly nonengineering measures such as changing inputs and cropping patterns. They also found that while early warning information was common, only $5 \%$ of villages received technical, financial, and physical support from local government for adaptation. ${ }^{62}$ In another analysis of government policies to assist households to cope with drought in the Lancang River (Yunnan Province), Li et al. ${ }^{63}$ list a range of relevant policies at national, provincial, and local levels, but do not assess the extent to which these are actually enhancing the adaptive capacity of farmers. Their study finds no evidence of the implementation of high-level adaptation policies at the local level.

In terms of barriers to adaptation there is limited analysis specific to China, though one study identifies money, knowledge, and shortages of farmland and labour as key barriers, ${ }^{64}$ while another briefly discusses lack of information and technical knowledge, and limited financial capacity. ${ }^{65}$ Another potential barrier is local government capacity: studies of disaster management capacity and rural poverty alleviation at the local level have highlighted major fiscal and institutional limitations, ${ }^{66,67}$ though to date there has been no analysis of local government capacity in relation to climate change adaptation.

While the vast majority of research focuses on the major grain crops, and is positioned at national and regional scales, a small collection of studies of vulnerability and adaptation at local scales have begun to draw attention to the diversity of agricultural systems and the ways in which the socio-economic and political context can shape vulnerability and the possibilities of adaptation. In the following section that context is considered further: what does China's agricultural sector look like today? 


\section{CONTEXT}

\section{China's Changing Agriculture}

China's agriculture has changed remarkably since the pre-reform period of agricultural collectives and mandatory state grain procurement. Farmland in China is still collectively owned, but farmers hold long-term leases over their allocated land, and with recent reforms can now legally subcontract that land. And while grain crops remain central to agriculture and food security, farmers are increasingly pursuing diversified and specialised livelihoods. With its entry into the World Trade Organization (WTO) in 2001 and associated structural adjustments, China has seen a concentration of production areas and the emergence of pillar industries. ${ }^{68}$ Distinct regional agricultural zones are being established for the major agricultural commodities, such as soybean and corn production in the north-east, oilseeds in the Yangtze watershed, cotton in the north-west, and nuts and wheat in the Huang-Huai-Hai region. ${ }^{69}$

High degrees of specialization occur at the local (village, township, county) scale, often driven by the growth of agribusiness companies that encourage the vertical integration-meaning scaling up of crop production in a region and integrating cultivation with processing and marketing — of smallholder farms. ${ }^{70,71}$ These changes signal a new era in China's agriculture more in line with its comparative advantage: a move away from land and capital-intensive production to higher-value, labour-intensive crops, and a wholesale shift from subsistence to cash crops. ${ }^{69,72}$ Part of this shift is China's emergence as the world's 'green grocer,' producing labour-intensive horticultural products such as fruit and vegetables. ${ }^{73}$ The rise in horticultural production is in response to changing domestic food consumption, but exports have increased as well, particularly of processed fruits and vegetables. ${ }^{74}$ As such, the amount of land used for grain crops is shrinking, and a rising proportion of grain is used for animal feed rather than for human consumption. ${ }^{71}$ For farmers, this shift from subsistence to cash crops often brings better net returns (particularly for fruit and vegetables), but also exposes them to new risks including reliance on intermediaries for storage, transportation, processing, and marketing. ${ }^{70,74}$

A central characteristic of agriculture in China has been that it is small-scale and family-based. Since the introduction of the Household Responsibility System in the early 1980s, land usage rights rest with households, while the village collective retains ownership. ${ }^{71}$ Despite rapid urbanization, overall per capita landholdings remain very low: in $2010,68 \%$ of farmers were farming on less than 0.67 ha and $38 \%$ on less than 0.33 ha. ${ }^{75}$ Given small landholdings, and the division of landholdings into non-contiguous plots (the effect of egalitarian land redistributions in the 1980s and 1990s), farmers engage in intensive agricultural practices including high fertiliser and pesticide application, and multiple-cropping. ${ }^{74}$ Of course, a rapid increase in off-farm employment has also taken place, reducing farmers' reliance on onfarm income. While some studies suggest that this income diversification is an important coping strategy, ${ }^{50}$ the relationship between vulnerability, adaptation, and off-farm activities demands further study, ${ }^{76}$ particularly as there is evidence that participation in off-farm income generation differs substantially by gender, education level, and wealth. ${ }^{77}$

This picture of small-scale, family-based agriculture is, however, changing, spurred on by the central government's continued push toward a scaled-up, mechanised, 'modern' agricultural sector (including in 2016's No. 1 Central Document ${ }^{78}$ ). Recent research has highlighted the extent of land transfers to the 'new agricultural entities' (新型农业经营主体 xinxing nongye jingying zhuti), including large-scale family farms, specialised farms, dragon-head enterprises, and cooperatives. ${ }^{79-82}$ This scaling-up of agricultural production in the hands of new entities will have significant implications for climate change adaptation (and more broadly the continuation of smallholder agriculture), which are yet to be explored in the academic literature. These new entities are likely to have quite different capacity to adapt (compared with smallholders) and may require different kinds of support from local government. In addition, smallholder farmers may now have to compete with scaled up farms for adaptation financing. But it is important to recognise that there is great regional diversity in this process. There are parts of Shanxi Province on the Loess Plateau, for instance, where there is very little evidence of land consolidation, where farming (though specialised) continues to be dominated by independently operating households on small, fragmented plots. ${ }^{56}$ In wealthier coastal provinces like Jiangsu, land transfer has advanced much more rapidly. ${ }^{83}$ Given the changes described in the preceding paragraphs in who farms, what they farm, and how they farm, how does current science and policy on agricultural adaptation stack up?

\section{FOUR ISSUES}

Framing

In policy documents, and also in the academic literature on impacts, agriculture is framed as a relatively 
homogenous sector. The vulnerability of agricultural systems is discussed largely in terms of grain (rice, wheat, corn) production, and typically as a percentage of grain yield reductions. International partnerships have also focused on climate change projections and demonstration projects for grain. Partly this is a problem of scale within models that project the interaction between crop phenology and climate, most of which are unable to represent heterogeneity among farms, communities, or regions. ${ }^{84}$ But a focus on yield reductions also fails to address the broader context of farmer livelihoods. Planned agricultural adaptation is about enhancing the decision-making and resources of millions of smallscale farmers in the context of other stressors such as entrenched poverty and constrained land resources. Focusing on yield reductions at a sectoral scale ignores the need to integrate adaptation into existing programs addressing sustainable livelihoods and poverty alleviation. It also ignores the differing financial capabilities of smallholders and scaled-up agricultural producers, who may require different forms of information, extension services, or financial support to successfully adapt.

Hence the frame-the construction of the policy problem-that gives meaning to translating adaptation objectives into policy, is flawed. ${ }^{85}$ China's agricultural sector is not homogenous: it has become increasingly diverse and regionally and locally specialised, as farmers have shifted into higher-value, labour-intensive crops, and as new forms of farming have emerged. While studies of vulnerability and adaptation at the local scale (as discussed under existing research) better reflect this reality, they do not carry the agenda-setting power of national adaptation policy and sectoral-scale modelling. Most adaptation science and policy fails to view China's agricultural systems as complex socioecological systems in which human interventions (including government interventions) are a significant source of complexity and uncertainty. ${ }^{84}$

\section{Vulnerability}

On-the-ground empirical studies of vulnerability in China ${ }^{49-51,56}$ highlight issues of poverty, inequality, land use, and climate as they intersect at the scale of household livelihoods. To some extent they highlight the role of the state in shaping adaptive strategies, and the potential for differences in vulnerability between and within rural communities. To ensure appropriate and effective planned adaptation, an understanding of vulnerability-the ability or inability to respond to any external stress placed on livelihoods ${ }^{86}$-is surely required. And yet there is little discussion of vulnerability in China's adaptation policy, and in the literature, in-depth studies of vulnerability are in the minority. The National Climate Change Adaptation Strategy is not based on an assessment of vulnerability at the sectoral or any other scale, but it does recommend adaptation measures for agriculture. It is likely that vulnerability will be explored in more detail in subsequent policies and plans: one of the strategy's guiding principles is 'highlighting the priorities,' that is, vulnerable areas and vulnerable people will be prioritised, based on a comprehensive evaluation of climate impacts. ${ }^{9}$ And yet a technical evaluation of impacts may tell us very little about vulnerability as a dynamic state, about how farmers' livelihoods interact with a specific set of impacts.

Vulnerability analyses allow us to identify who is vulnerable and why, thereby guiding planned adaptation. Unfortunately, the insights of vulnerability studies in China (discussed above) are poorly reflected in the broader literature and policy. In seeking to understand why people are vulnerable, a vulnerability lens links climate change impacts to existing pressures on livelihoods and to the broader economic and political context. It draws attention to double exposure and the ways in which vulnerability is shaped by current socioeconomic trends, but also by structural economic changes driven by global economic forces. ${ }^{87}$ Double exposure and multiple stressors have been well documented in developed and developing country contexts. ${ }^{88-92}$ In an authoritarian state in the midst of a transition to a market economy where land is not privatised and where labour still does not necessarily move freely, these forces manifest in particular ways: post-WTO agricultural restructuring, vertical integration of family farms through agribusiness companies, and in the broader economic context, decentralization of expenditure responsibilities but inadequate resourcing of local governments, and growing inequality within and between rural areas. But capitalism with Chinese characteristics also means that Chinese farmers have been the beneficiaries of increasing flows of cash subsidies, a new rural pension program, a new rural health insurance program and various agricultural productivity, village infrastructure and poverty alleviation projects, all part of the central government's renewed concern for 'left-behind' rural areas. More so than in other places, therefore, the effects of double exposure may be somewhat mitigated by the state. However, now agribusinesses, subsidised by the central government, are moving into the countryside and reshaping access to, and control over land, 
labour, and capital. The potential for accelerated social differentiation as a result of this process ${ }^{81}$ suggests that the nature of double exposure in the Chinese countryside is changing and that new questions must be asked about whether vertical integration makes smallholder farms more or less vulnerable.

The importance of understanding vulnerability also lies in being able to achieve fair adaptation (adaptation that reduces the vulnerability of the most vulnerable), while avoiding maladaptation (adaptation that increases vulnerability). ${ }^{93,94}$ Vulnerability analyses should attune us to the ways in which climate change is not a generalised threat to an undifferentiated rural population; rather, impacts and adaptation interventions are experienced through the lens of a stratified society and its uneven distribution of wealth and resources. ${ }^{95,96}$ This has been discussed in relation to urban China, ${ }^{97}$ but not rural. It is widely accepted that the poor are more vulnerable to climatic shocks and less able to adapt, and it is assumed that climate change will exacerbate existing inequalities. ${ }^{98}$ This relationship between vulnerability and poverty/inequality is highly relevant to contemporary China, which is experiencing rising inequality in income, assets, and opportunity at multiple scales. Inequality is no longer just an urban-rural or coastinland gap: within rural China there is growing inequality at the county and even village levels, which current policies are proving inadequate in addressing. ${ }^{99,100}$ Agricultural modernization and land transfers are also rapidly producing new forms of social differentiation. ${ }^{70}$ The current discourse in China's adaptation policy does not recognise this vulnerability-poverty nexus. It is a further example of how apolitical framings, simplifying discourses and technocratic policies work to conceal questions of equity and justice. ${ }^{95}$

\section{Engineered Solutions}

Some of the measures proposed in China's National Climate Change Adaptation Strategy and elsewhere are no-regrets measures that if rolled out nationwide, would certainly benefit smallholder and other farmers: improved early warning systems for extreme weather events, disaster prevention measures, disaster insurance, soil moisture monitoring stations, and skills training for farmers. As identified in the literature, farmers are receiving very little support of this nature from local governments or elsewhere. Some caution is warranted with future extension services targeted at climate change adaptation. Some studies conclude that extensions services have a significant influence on farmers' adaptation to climate change because they provide access to information and new agricultural developments. ${ }^{65}$ But others points to problems with current extension services in that farmers do not necessarily trust the advice of extension agents or do not get the follow-up support they need to implement new practices or technologies. ${ }^{101}$

But overall, greater emphasis is placed on largescale technical or engineered interventions targeted at crop productivity, such as replacing crop varieties, changing cropping patterns, building additional water resource infrastructure, and moving people. That such an approach is evident in adaptation policy documents is unsurprising given the strong bias in China, particularly in relation to managing its environment, toward engineered solutions or 'engineering as panacea. ${ }^{102}$ More broadly this reflects a particular way of thinking about nature, which has held sway within the Chinese state for a very long time. ${ }^{103-105}$ Such strategies are not conducive to community participation in adaptation, despite 'extensive participation' being one of the guiding principles identified in the National Climate Change Adaptation Strategy. ${ }^{9}$

The viability of such large-scale, engineered adaptive solutions must be questioned. Requirements to meet targets for expanding irrigation capacity in a tightly controlled political environment could lead to the building of political achievement or 'vanity' projects which advance the interests of local officials but bring little benefit to farmers. ${ }^{106}$ There is some evidence of new pipes laying unused in fields when they are most needed because of water shortages. ${ }^{56}$ Changing cropping patterns or varieties may work for annual grain crops, but are far more difficult for specialised perennial crops that are long-term investments. It is understood that many farmers are reluctant to invest in new technologies, to adopt new crop varieties, and to increase crop production because of high inputs costs. ${ }^{101}$ And some technologies may not be suitable for fragmented small-scale farmland, as others have found in relation to drip and sprinkler irrigation, ${ }^{101}$ again highlighting the probable differences in vulnerability and adaptation between smallholders and largerscale producers. Resettlement is identified in policy documents and in the academic literature ${ }^{107}$ as an important adaptive measure for drought in northern China, and yet resettlement carries such significant risks to farmer livelihoods. ${ }^{56}$ The effectiveness of engineered solutions also hinges on local government implementation, which is the final issue to consider. 


\section{Local Government Capacity}

While elsewhere there have been calls to decentralise adaptation planning and implementation to local government (and non-government) actors, ${ }^{108,109}$ insufficient attention has been paid to what this means in a Chinese context. In the absence of a functioning civil society, the local state is and will continue to be the key actor in planned adaptation, as it is in poverty alleviation, rural development, and agricultural modernization. But what little has been written to date suggests that China's local governments tend to be weak and poorly funded, engage in little consultation with communities and other stakeholders, and have few incentives to properly implement higher-level climate policies. ${ }^{3,110,111}$ In relation to environmental policies, an implementation gap is well documented, whereby central government ambitions are loosely enforced at the local level. ${ }^{112}$ In terms of incentives, there is certainly evidence of energy efficiency targets being integrated into the performance evaluations of local officials, ${ }^{113}$ but progress in adaptation to climate change is much less easily quantified.

Besides incentives we must also consider the fiscal environment. Adaptation depends on expanding household access to resources, and local government has a considerable role in enabling or disabling this expansion through mediating household livelihood opportunities. $^{89,114}$ But the political economy of some agricultural counties in China is such that the most vulnerable are unlikely to receive assistance if future adaptation funding is channeled through the current fiscal system. This political economy is well documented in relation to poverty alleviation and rural development, but needs to be better understood in relation to climate change adaptation. First, China's current fiscal system is not very good at distributing resources in an equitable way amongst provinces and local governments depending on need. In fact, it is considered to disadvantage agricultural counties, to aggravate existing disparities in fiscal capacity and to jeopardise rural public service provision in poorer areas. ${ }^{115-120}$ Second, once resources reach agricultural counties, local governments are known to channel their limited resources into particular villages, usually 'model' villages. ${ }^{67,121}$ They are not necessarily responsive to need, given the political incentives at play in China's hybrid party-state system. If funding for adaptation flows through the fiscal system it is therefore not guaranteed to reach the areas most in need of resources, nor the people within these areas who may be most vulnerable.

Also relevant to this discussion is that new agricultural entities are beginning to capture a significant portion of the central government resources flowing to the countryside. ${ }^{122}$ This is described elsewhere as politically assisted accumulation. ${ }^{80}$ At this point it is unclear how resources will be allocated between smallholders and bigger players in the agricultural sector.

Assuming that adaptation financing will flow through the current fiscal system, and that local governments will play a key role in implementation, we can reasonably deduce that the mechanism for agricultural adaptation is flawed. To achieve fair adaptation (to reach the most vulnerable), the challenges embedded in China's rural political economy, which constrain institutional capacity for adaptation, must be recognised and some attempt made to overcome them. The localization of adaptation in China carries risks, risks that are poorly recognised in current adaptation science and policy; though beyond China the tensions between the oft-repeated 'localness' of adaptation and actual local capacity for implementation are beginning to be elucidated. ${ }^{123,124}$ Strategies developed with farmer participation and attuned to the intersection of climatic risk and local livelihoods, coupled with the adequate financing of local governments in under-resourced agricultural areas (which would necessitate delivering funds through an alternative route), are one possible way forward.

\section{CONCLUSION}

This review offers an opportunity to reflect on the current state of adaptation science and policy as it relates to agriculture in China. At present, the framing of the problem is inaccurate, vulnerability is poorly understood, many of the solutions proposed are questionable, and the mechanism for adaptation is flawed. There appears to be a major disconnect between the current policy discourse (and the majority of adaptation research) and the reality on the ground. And yet this discourse is an increasingly influential one: as China ramps up its climate leadership through the South-South Cooperation on Climate Change Forum and the new South-South Cooperation Fund on Climate Change, ${ }^{125}$ we can expect that its experiences in adaptation policy and practice will be formative for other developing countries.

China has a long way to go in positioning itself to successfully adapt to the impacts of climate change on agriculture. As provincial and sub-provincial adaptation policy-making and implementation proceeds, it is hoped that more nuanced strategies based on an understanding of local vulnerability contexts 
and developed with input from local communities, emerge. In this process, the guiding principles of the National Climate Change Adaptation Strategy need to be given more weight: if realised, they have the potential to shape much better outcomes. For scholars, the task is twofold. Given the dearth of literature on China's adaptation policy and practice, there is a need to trace the process of adaptation from high-level policy to local practice and to document who benefits and who does not. There is also a need for multi-disciplinary research that moves beyond the current focus to assess climate change impacts on specialised agriculture (particularly fruit and vegetable production), and to identify appropriate adaptation strategies for smallholder and larger-scale farms that can inform local adaptation practice.

\section{REFERENCES}

1. National Development and Reform Commission. Second national communication on climate change of the People's Republic of China, 2012. Available at: http:// unfccc.int/essential_background/library/items/3599. php?rec=j\&priref=7666\#beg

2. Morton K. China and the global environment: learning from the past, anticipating the future. Lowy Institute Paper 2009. Vol. Paper 29. Available at: http:H W. Publieation.asp?pid=1186

3. Li B. Governing urban climate change adaptation in China. Environ Urban 2013, 25:413-427.

4. State Development and Planning Commission. The People's Republic of China initial national communication on climate change, 2004. Available at: http:// unfccc.int/resource/docs/natc/chnnc1e.pdf

5. National Development and Reform Commission. China's policies and actions for addressing climate change, 2012. Available at: www.ccchina.gov.cn/Web Site/CCChina/UpFile/File1324.pdf.

6. National Development and Reform Commission. China's policies and actions on climate change, 2014. Available at: http://en.cchina.gov.cn/list.aspx? clmId $=107$.

7. National Development and Reform Commission. Guojia yingdui qihou bianhua guihua (2014-2020 nian) 国家应对气候变化规划 (National Climate Change Plan 2014-2020). Available at: http://www. ndrc.gov.cn/zcfb/zcfbtz/201411/t20141104_642612. html (Accessed February 9, 2015).

8. National Development and Reform Commission. Intended nationally determined contribution: enhanced actions on climate change. Available at: http://www4.unfccc.int/submissions/indc/Submission $\%$ 20Pages/submissions.aspx (Accessed August 6, 2015).

9. National Development and Reform Commission. Guojia shiying qihou bianhua zhanlue 国家适应气候 变化战略 (National Climate Change Adaptation Strategy), 2013. Available at: http://www.gov.cn/gzdt/ att/att/site1/20131209/001e3741a2cc140f6a8701.pdf

10. Uchida E, Xu J, Rozelle S. Grain for green: costeffectiveness and sustainability of China's conservation set-aside program. Land Econ 2005, 81:247-264.

11. Feng L, Xu J. Farmers' willingness to participate in the next-stage Grain-for-Green Project in the Three Gorges Reservoir Area, China. Environ Manage 2015, 56:505-518.

12. Shanxi Provincial Government General Office. Guanyu yinfa shanxi sheng yingdui qihoubiahua banfa 关 于印发山西省应对气候变化办法的通知 (On the issuance of notice of approaches to address climate change in Shanxi Province). Available at: http://www. shanxigov.cn/n16/n1116/n1458/n1518/n34105/1534 3704.html (Accessed January 20, 2015).

13. ACCC. Key research findings: agriculture. ACCC key research findings, 2012. Available at: http://www.cca daptation.org.cn/ACCC_en/item_1447887_0.html

14. World Bank. China: GEF supports demonstration of climate smart crop production. Available at: http:// www.worldbank.org/en/news/press-release/2014/09/ 05/china-gef-supports-demonstration-of-climate-smartcrop-production (Accessed January 21, 2015).

15. Zhu XF, Zhao AZ, Li YZ, Liu XF. Agricultural irrigation requirements under future climate scenarios in China. J Arid Land 2014, 7:224-237.

16. Tao F, Yokozawa M, Xu Y, Hayashi Y, Zhang Z. Climate changes and trends in phenology and yields of field crops in China, 1981-2000. Agric For Meteorol 2006, 138:82-92.

17. Tao F, Zhang Z, Yokozawa M. Dangerous levels of climate change for agricultural production in China. Reg Environ Change 2011, 11:41-48.

18. Xiong W, Holman I, You L, Yang J, Wu W. Impacts of observed growing-season warming trends since 1980 on crop yields in China. Reg Environ Change 2014, 14:7-16.

19. Li RL, Geng S. Impacts of climate change on agriculture and adaptive strategies in China. J Integr Agric 2013, 12:1402-1408.

20. Xiong W, Holman I, Lin E, Conway D, Jiang J, $\mathrm{Xu} \mathrm{Y,} \mathrm{Li} \mathrm{Y.} \mathrm{Climate} \mathrm{change,} \mathrm{water} \mathrm{availability} \mathrm{and}$ future cereal production in China. Agr Ecosyst Environ 2010, 135:58-69. 
21. Xiong W, Conway D, Lin E, Holman I. Potential impacts of climate change and climate variability on China's rice yield and production. Clim Res 2009, 40:23-35.

22. Mo X, Guo R, Liu S, Lin Z, Hu S. Impacts of climate change on crop evapotranspiration with ensemble GCM projections in the North China Plain. Clim Change 2013, 120:299-312.

23. Yang X, Lin E, Ma S, Ju H, Guo L, Xiong W, Li Y, $\mathrm{Xu} \mathrm{Y}$. Adaptation of agriculture to warming in Northeast China. Clim Change 2007, 84:45-58.

24. Liu S, Mo X, Lin Z, Xu Y, Ji J, Wen G, Richey J. Crop yield responses to climate change in the HuangHuai-Hai Plain of China. Agric Water Manage 2010, 97:1195-1209.

25. Ju H, Conway D, Li Y, Harvey A, Lin E, Calsamiglia-Mendlewicz S. Adaptation framework and strategy part 2: application of the adaptation framework: a case study of Ningxia, Northwest China. Impacts of Climate Change on Chinese Agriculture-Phase II, 2008.

26. Lin E, Xiong W, Ju H, Xu Y, Li Y, Bao L, Xie L. Climate change impacts on crop yield and quality with $\mathrm{CO}_{2}$ fertilization in China. Philos Trans $\mathrm{R}$ Soc Lond B: Biol Sci 2005, 360:2149-2154.

27. Challinor AJ, Simelton ES, Fraser EDG, Hemming D, Collins M. Increased crop failure due to climate change: assessing adaptation options using models and socio-economic data for wheat in China. Environ Res Lett 2010, 5:1-8.

28. Piao S, Ciais P, Huang Y, Shen Z, Peng S, Li J, Zhou L, Liu H, Ma Y, Ding Y, et al. The impacts of climate change on water resources and agriculture in China. Nature 2010, 467:43-51.

29. Wang JX, Huang JK, Yang J. Overview of impacts of climate change and adaptation in China's agriculture. J Integr Agric 2014, 13:1-17.

30. Thomas A. Agricultural irrigation demand under present and future climate scenarios in China. Global Planet Change 2008, 60:306-326.

31. Zhang HL, Zhao X, Yin XG, Liu SL, Xue JF, Wang $\mathrm{M}, \mathrm{Pu} \mathrm{C}$, Lal R, Chen F. Challenges and adaptations of farming to climate change in the North China Plain. Clim Change 2015, 129:213-224.

32. Lin E. Agricultural vulnerability and adaptation to global warming in China. Water Air Soil Pollut 1996, 92:63-73.

33. Smit B, Cai Y. Climate change and agriculture in China. Glob Environ Change 1996, 6:205-214.

34. Chavas DR, Izaurralde RC, Thomson AM, Gao X. Long-term climate change impacts on agricultural productivity in eastern China. Agric For Meteorol 2009, 149:1118-1128.

35. Yao F, Xu Y, Lin E, Yokozawa M, Zhang J. Assessing the impacts of climate change on rice yields in the main rice areas of China. Clim Change 2007, 80:395-409.

36. Xiong W, Matthews R, Holman I, Lin E, Xu Y. Modelling China's potential maize production at regional scale under climate change. Clim Change 2007, $85: 433-451$.

37. Zhao HY, Guo JQ, Zhang CJ, Sun LD, Zhang XD, Lin JJ, Wang YH, Fang F, Ma PL, Liu CH, et al. Climate change impacts and adaptation strategies in Northwest China. Adv Clim Change Res 2014, 5:7-16.

38. Xiong W, Conway D, Lin E, Xu Y, Ju H, Jiang J, Holman I, Li Y. Future cereal production in China: the interaction of climate change, water availability and socio-economic scenarios. Glob Environ Change 2009, 19:34-44.

39. Ye L, Xiong W, Li Z, Yang P, Wu W, Yang G, Fu Y, Zou J, Chen Z, Van Ranst E, et al. Climate change impact on China food security in 2050. Agron Sustain Dev 2013, 33:363-374.

40. Zhang C, McBean EA. Adaptation investigations to respond to climate change projections in Gansu Province, Northern China. Water Resour Manage 2014, 28:1531-1544.

41. Wang J, Huang X, Zhong T, Chen Z. Climate change impacts and adaptation for saline agriculture in north Jiangsu Province, China. Environ Sci Policy 2013, 25:83-93.

42. Wang J, Mendelsohn R, Dinar A, Huang J-K, Rozelle S, Zhang L. The impact of climate change on China's agriculture. Agric Econ 2009, 40:323-337.

43. Wang JX, Huang JK, Rozelle S. Climate change and China's agricultural sector: an overview of impacts, adaptation and mitigation. 2010.

44. Liu H, Li X, Fischer G, Sun L. Study on the impacts of climate change on China's agriculture. Clim Change 2004, 65:125-148.

45. Chen Y, Wu Z, Okamoto K, Han X, Ma G, Chien H, Zhao J. The impacts of climate change on crops in China: a Ricardian analysis. Global Planet Change 2013, 104:61-74.

46. Zhou L, Turvey CG. Climate change, adaptation and China's grain production. China Econ Rev 2014, 28:72-89.

47. Li Y, Xiong W, Hu W, Berry $\mathrm{P}$, Ju H, Lin E, Wang W, Li K, Pan J. Integrated assessment of China's agricultural vulnerability to climate change: a multi-indicator approach. Clim Change 2014, 128:355-366.

48. Dong Z, Pan Z, An P, Wang L, Zhang J, He D, Han H, Pan X. A novel method for quantitatively evaluating agricultural vulnerability to climate change. Ecol Indic 2015, 48:49-54. 
49. Zheng Y, Byg A, Thorsen BJ, Strange N. A temporal dimension of household vulnerability in three rural communities in Lijiang, China. Hum Ecol 2013:1 13.

50. Su Y, Xu J, Wilkes A, Lu J, Li Q, Fu Y, Ma X, Grumbine RE. Coping with climate-induced water stresses through time and space in the mountains of Southwest China. Reg Environ Change 2012, 12:855-866.

51. Liu C, Golding D, Gong G. Farmers' coping response to the low flows in the lower Yellow River: a case study of temporal dimensions of vulnerability. Glob Environ Change 2008, 18:543-553.

52. Xu J, Fox J, Vogler JB, Zhang P, Fu Y, Yang L, Qian J, Leisz S. Land-use and land-cover change and farmer vulnerability in Xishuangbanna Prefecture in southwestern China. Environ Manage 2005, 36:404-413.

53. Knutsson P, Ostwald M. A process-oriented sustainable livelihoods approach: a tool for increased understanding of vulnerability, adaptation and resilience. Mitig Adapt Strat Global Change 2006.

54. Hageback J, Sundberg J, Ostwald M, Chen D, Yun X, Knutsson P. Climate variability and land-use change in Danangou watershed, China-examples of small-scale farmers' adaptation. Clim Change 2005, 72:189-212.

55. Li C, Tang Y, Luo H, Di B, Zhang L. Local farmers' perceptions of climate change and local adaptive strategies: a case study from the Middle Yarlung Zangbo River Valley, Tibet, China. Environ Manage 2013, 52:894-906.

56. Rogers S, Xue T. Resettlement and climate change vulnerability: evidence from rural China. Glob Environ Change 2015, 35:62-69.

57. Yan J, Wu Y, Zhang Y. Adaptation strategies to pasture degradation: gap between government and local nomads in the eastern Tibetan Plateau. J. Geogr. Sci. 2011, 21:1112-1122.

58. Zhang C, Li W, Fan M. Adaptation of herders to droughts and privatization of rangeland-use rights in the arid Alxa Left Banner of Inner Mongolia. J Environ Manage 2013, 126:182-190.

59. Fu Y, Grumbine RE, Wilkes A, Wang Y, Xu JC, Yang YP. Climate change adaptation among Tibetan pastoralists: challenges in enchancing local adaptation through policy support. Environ Manage 2012, 50:607-621.

60. Xu J, Grumbine RE. Building ecosystem resilience for climate change adaptation in the Asian highlands. WIREs Clim Change 2014, 5:709-718.

61. Wang J, Brown DG, Agrawal A. Climate adaptation, local institutions, and rural livelihoods: a comparative study of herder communities in Mongolia and Inner Mongolia, China. Global Environ Change 2013. In press. $_{2}$
62. Chen H, Wang J, Huang J. Policy support, social capital, and farmers' adaptation to drought in China. Glob Environ Change 2013.

63. Li H, Gupta J, Van Dijk MP. China's drought strategies in rural areas along the Lancang River. Water Policy 2013, 15:1-18.

64. Zheng Y, Dallimer M. What motivates rural households to adapt to climate change? Clim Dev 2015. In press.

65. Kibue GW, Liu X, Zheng J, Zhang X, Pan G, Li L, Han X. Farmers' perceptions of climate variability and factors influencing adaptation: evidence from Anhui and Jiangsu, China. Environ Manage 2016:1 11.

66. Zhang Q, Lu Q, Hu Y, Lau J. What constrained disaster management capacity in the township level of China? Case studies of Wenchuan and Lushan earthquakes. Nat Hazards 2015, 77:1915-1938.

67. Rogers S. Betting on the strong: local government resource allocation in China's poverty counties. J Rural Stud 2014, 36:197-206.

68. OECD. Agricultural Policies in China After WTO Accession. Paris: OECD Publications; 2002.

69. Zhou L. China's agricultural development. In: Garnaut R, Fang C, Song L, eds. China: A New Model for Growth and Development. Canberra: ANU E Press; 2013.

70. Zhang QF, Donaldson JA. The rise of agrarian capitalism with Chinese characteristics: agricultural modernization, agribusiness and collective land rights. China J 2008:25-47.

71. Huang PCC. China's new-age small farms and their vertical integration: agribusiness or co-ops? Mod China 2011, 37:107-134.

72. Duan X, Dwyer W. Rethinking China's domestic agriculture support measures under WTO protocols. J Asia Pac Econ 2008, 13:82-98.

73. Veeck G, Carpenter V, Lee S, Chung H, Liu Z, Kanda K, Narita T, Huang X. Post-WTO agriculture in East Asia: a case study of apple products. Asian Geogr 2006, 25:173-191.

74. Lohmar B, Gale F, Tuan F, Hansen J. China's ongoing agricultural modernization: challenged remain after 30 years of reform. 2009. Available at: http:// www.ers.usda.gov/publications/eib-economic-informa tion-bulletin/eib51.aspx

75. National Bureau of Statistics. China's Second National Agriculture Census Data Compilation (Rural Volume), 2010.

76. Burnham M, Ma Z. Linking smallholder farmer climate change adaptation decisions to development. Clim Dev 2015,

77. Démurger S, Fournier M, Yang W. Rural households' decisions towards income diversification: evidence 
from a township in northern China. China Econ Rev 2010, 21:S32-S44.

78. Sina. 2016 nian zhongyang yihao wenjian gongbu 2016 年中央一号文件公布 (2016 No. 1 Central Document Published). Available at: http://news.sina.com. $\mathrm{cn} / \mathrm{c} / 2016-01-28 /$ doc-ifxnzanh0163964.shtml (Accessed February 2, 2016).

79. Huang Y. Can capitalist farms defeat family farms? The dynamics of capitalist accumulation in shrimp aquaculture in South China. J Agrar Change 2015, 15:392-412.

80. Zhang QF. Class differentiation in rural China: dynamics of accumulation, commodification and state intervention. J Agrar Change 2015, 15:338-365.

81. Yan HR, Chen YY. Agrarian capitalization without capitalism? Capitalist dynamics from above and below in China. J Agrar Change 2015, 15:366-391.

82. Schneider M. What, then, is a Chinese peasant? Nongmin discourses and agroindustrialization in contemporary China. Agric Hum Values 2015, 32:331-346.

83. Xie Y, Jiang Q. Land arrangements for rural-urban migrant workers in China: findings from Jiangsu Province. Land Use Policy 2016, 50:262-267.

84. Preston BL, King AW, Ernst KM, Absar SM, Nair SS, Parish ES. Scale and the representation of human agency in the modeling of agroecosystems. Curr Opin Environ Sustain 2015 - In press.

85. Fünfgeld H, McEvoy D. Frame divergence in climate change adaptation policy: insights from a australian local government planning. Environ Plann C: Govern Policy 2014, 32:603-622.

86. Kelly PM, Adger NW. Theory and practice in assessing vulnerability to climate change and facilitating adaptation. Clim Change 2000, 47:325-352.

87. O’Brien KL, Leichenko RM. Double exposure: assessing the impacts of climate change within the context of economic globalization. Glob Environ Change 2000, 10:221-232.

88. Belliveau S, Smit B, Bradshaw B. Multiple exposures and dynamic vulnerability: evidence from the grape industry in the Okanagan Valley, Canada. Glob Environ Change 2006, 16:364-378.

89. Eakin H. Institutional change, climate risk, and rural vulnerability: cases from Central Mexico. World Dev 2005, 33:1923-1938.

90. O’Brien K, Leichenko R, Kelkar U, Venema H, Aandahl G, Tompkins H, Javed A, Bhadwal S, Barg S, Nygaard L, et al. Mapping vulnerability to multiple stressors: climate change and globalization in India. Glob Environ Change 2004, 14:303-313.

91. Silva JA, Eriksen S, Ombe ZA. Double exposure in Mozambique's Limpopo River Basin. Geogr J 2010, 176:6-24.
92. Tschakert P. Views from the vulnerable: understanding climatic and other stressors in the Sahel. Glob Environ Change 2007, 17:381-396.

93. Barnett J, O’Neill SJ. Minimising the risk of maladaptation: a framework for analysis. In: Palutikof JP, Boulter SL, Ash AJ, Stafford-Smith M, Parry M, Waschka M, Guitart D, eds. Climate Adaptation Futures. West Sussex: Wiley-Blackwell; 2013, 87-93.

94. Adger WN. Vulnerability. Glob Environ Change 2006, 16:268-281.

95. Smucker TA, Wisner B, Mascarenhas A, Munishi P, Wangui EE, Sinha G, Weiner D, Bwenge C, Lovell E. Differentiated livelihoods, local institutions, and the adaptation imperative: Assessing climate change adaptation policy in Tanzania. Geoforum 2015, 59:39-50.

96. Marino E, Ribot J. Special issue introduction: adding insult to injury: climate change and the inequities of climate intervention. Glob Environ Change 2012, 22:323-328.

97. Tan Y, Liu X, Hugo G. Exploring relationship between social inequality and adaptations to climate change: evidence from urban household surveys in the Yangtze River delta, China. Popul Environ 2015, 36:400-428.

98. Leichenko R, Silva JA. Climate change and poverty: vulnerability, impacts, and alleviation strategies. WIREs Clim Change 2014, 5:539-556.

99. Alm J, Liu Y. China's tax-for-fee reform and village inequality. Oxford Dev Stud 2013- In press.

100. Sun W, Wang X, Bai CE. Income inequality and mobillity of rural households in China from 2003 to 2006. China Agric Econ Rev 2014, 6:73-91.

101. Burnham M, Ma Z, Zhu D. The human dimensions of water saving irrigation: lessons learned from Chinese smallholder farmers. Agric Hum Values 2015, 32:347-360.

102. Chen SJ. Water resoure scarcity in China. In: Keeley J, Zheng YS, eds. Green China: Chinese Insights on Environment and Development. London: International Institute for Environment and Development; 2011, 84-96.

103. Elvin M. The environmental legacy of Imperial China. In: Edmonds RL, ed. Managing the Chinese Environment. Oxford and New York: Oxford University Press; 1998, 9-32.

104. Shapiro J. Mao's War Against Nature: Politics and the Environment in Revolutionary China. Cambridge: Cambridge University Press; 2001.

105. Economy EC. The River Runs Black: The Environmental Challenge to China's Future. Ithaca, NY and London: Cornell University Press; 2004.

106. Zhong Y. Local Government and Politics in China: Challenges From Below. M.E. Sharpe: New York, NY and London; 2003. 
107. Yang J, Tan C, Wang S, Wang S, Yang Y, Chen H. Drought adaptation in the Ningxia Hui Autonomous Region, China: Actions, planning, pathways and barriers. Sustainability 2015, 7:15029-15056.

108. Agrawal A, Perrin N, Chhatre A, Benson CS, Kononen M. Climate policy processes, local institutions, and adaptation actions: mechanisms of translation and influence. WIREs Clim Change 2012, 3:565-579.

109. Agrawal A. The role of local institutions in adaptation to climate change. In: Social Dimensions of Climate Change.2008.

110. Li H, Van Dijk MP. Climate change and farmers response in rural China. Int J Water 2012, 6:290-310.

111. Qi Y, Wu T. The politics of climate change in China. WIREs Clim Change 2013, 4:301-313.

112. Ran R. Perverse incentive structure and policy implementation gap in China's local environmental politics. J Environ Policy Plann 2013, 15:17-39.

113. Kostka G, Hobbs W. Local energy efficiency policy implementation in China: bridging the gap between national priorities and local interests. China $Q$ 2012:765-785.

114. McDowell JZ, Hess JJ. Accessing adaptation: multiple stressors on livelihoods in the Bolivian highlands under a changing climate. Glob Environ Change 2012, 22:342-352.

115. Duan H, Zhan JV. Fiscal transfer and local public expenditure in China: a case study of Shanxi Province. China Rev 2011, 11:57-88.

116. Tsui KY. Local tax system, intergovernmental transfers and China's local fiscal disparities. J Comp Econ 2005, 33:173-196.

117. Wong C. Can China change development paradigm for the 21st century? Fiscal policy options for $\mathrm{Hu}$
Jintao and Wen Jiabao after two decades of muddling through, German Institute for International and Security Affairs Working Paper, 2005.

118. World Bank. From poor areas to poor people: China's evolving poverty reduction agenda, 2009. Available at: http://documents.worldbank.org/ curated/en/2009/03/10444409/china-poor-areas-poorpeople-chinas-evolving-poverty-reduction-agenda-ass essment-poverty-inequality-china-vol-1-2-main-report

119. Brehm S. Fiscal incentives, public spending, and productivity-county-level evidence from a Chinese province. World Dev 2013, 46:92-103.

120. Göbel C. Uneven policy implementation in rural China. China J 2011, 65:53-76.

121. Schubert G, Ahlers AL. County and township cadres as a strategic group: "Building a New Socialist Countryside" in three provinces. China J 2012, 67:67-86.

122. Caixin. Zhongyang caizheng yindao nongye fazhan fangshi zhuanbian 中央财政引导农业发展方式转变 (Central government finances to guide transformation of agricultural development mode). Available at: http://finance.caixin.com/2015-12-30/100894452. html (Accessed January 28, 2016).

123. Nalau J, Preston BL, Maloney MC. Is adaptation a local responsibility? Environ Sci Policy 2015, 48:89-98.

124. Baker I, Peterson A, Brown G, McAlpine C. Local government response to the impacts of climate change: an evaluation of local climate adaptation plans. Landscape Urban Plan 2012, 107:127-136.

125. UNEP International Ecosystem Management Partnership. Forum promotes climate action through southsouth cooperation. Available at: http://www.unepiemp.org/content/forum-promotes-climate-actionthrough-south-south-cooperation (Accessed August 12, 2015). 


\section{QUERIES TO BE ANSWERED BY AUTHOR}

IMPORTANT NOTE: Please mark your corrections and answers to these queries directly onto the proof at the relevant place. DO NOT mark your corrections on this query sheet.

\section{Queries from the Copyeditor:}

AQ1. Please confirm that given names (red) and surnames/family names (green) have been identified correctly.

AQ2. A running head short title was not supplied; please check if this one is suitable and, if not, please supply a short title that can be used instead.

AQ3. Please spell out RMB.

AQ4. The sentence 'In policy documents...' has been reworded for clarity. Please check and confirm it is correct.

AQ5. References have been renumbered both in the text and in the reference list in order to maintain sequential order. Please check and confirm.

AQ6. Please provide the accessed date in Refs. [1,2,4-6,9,11,72,116].

AQ7. Please check and confirm if the URL provided in Refs. [2,76] are correct and active.

AQ8. Please provide the details of publisher name and location in Ref. [23].

AQ9. Please provide the journal title, volume number and page range in Ref. [41].

AQ10. Please provide Volume number for Ref. [49].

AQ11. Please provide Volume number, Page range for ref. [53].

AQ12. Please provide Volume number, Page range for ref. [61].

AQ13. Please provide Volume number, Page range for ref. [62].

AQ14. Please provide Volume number, Page range for ref. [64].

AQ15. Please provide Volume number for Ref. [65].

AQ16. Please provide Volume number for Ref. [70].

AQ17. Please provide Publisher name, Publisher location for Ref. [75].

AQ18. Please provide Volume number, Page range for ref. [76].

AQ19. Please provide Volume number, Page range for ref. [84].

AQ20. Please provide Volume number, Page range for ref. [99].

AQ21. Please provide Publisher name, Publisher location for Ref. [109].

AQ22. Please provide Volume number for Ref. [113]. 
Required software to e-Annotate PDFs: Adobe Acrobat Professional or Adobe Reader (version $\mathbf{7 . 0}$ or above). (Note that this document uses screenshots from Adobe Reader $\mathbf{X}$ )

The latest version of Acrobat Reader can be downloaded for free at: http://get.adobe.com/uk/readerl

Once you have Acrobat Reader open on your computer, click on the Comment tab at the right of the toolbar:

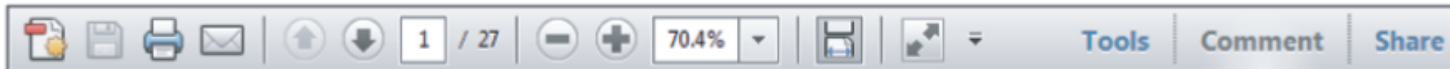

This will open up a panel down the right side of the document. The majority of tools you will use for annotating your proof will be in the Annotations section, pictured opposite. We've picked out some of these tools below:

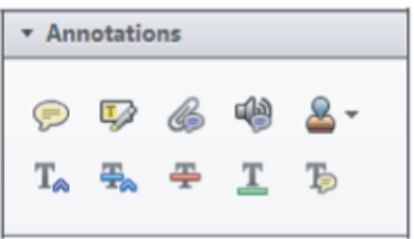

1. Replace (Ins) Tool - for replacing text.

军 Strikes a line through text and opens up a text box where replacement text can be entered.

\section{How to use it}

- Highlight a word or sentence.

- Click on the Replace (Ins) icon in the Annotations section.

- Type the replacement text into the blue box that appears.

1dard tramework for the analysis of $\mathrm{m}$ icy Nevertheless, it alse-led to exog،

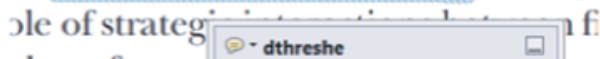
aber of comp 08/06/2011 15:58:17 : is that the $\mathrm{si}$, which led of nain compo bo level, are exc nc

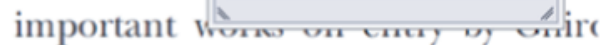
M heneferth) 1 we snen the 'hlarl 1

3. Add note to text Tool - for highlighting a section to be changed to bold or italic.

T. Highlights text in yellow and opens up a text box where comments can be entered.

\section{How to use it}

- Highlight the relevant section of text.

- Click on the Add note to text icon in the Annotations section.

- Type instruction on what should be changed regarding the text into the yellow box that appears.

namic responses of mark ups ent with the VAR evidence

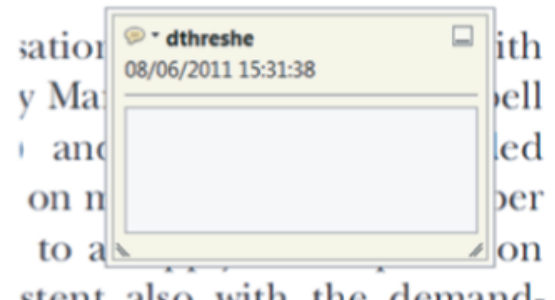

2. Strikethrough (Del) Tool - for deleting text.

Strikes a red line through text that is to be deleted.

\section{How to use it}

- Highlight a word or sentence.

- Click on the Strikethrough (Del) icon in the Annotations section.

there is no room for extra prohts al : ups are zero and the number of set) values are not determined by Blanchard and Kivetaki (1987), sfect competition in general equilil ts of aggregate demand and supply lassical framework assuming monol een on evorensue number of firms

4. Add sticky note Tool - for making notes at specific points in the text.

Marks a point in the proof where a comment needs to be highlighted.

How to use it

- Click on the Add sticky note icon in the Annotations section.

- Click at the point in the proof where the comment should be inserted.

- Type the comment into the yellow box that appears.

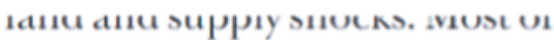

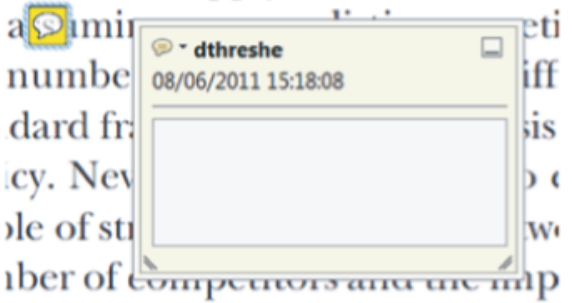

is that the structure of the sects: 
5. Attach File Tool - for inserting large amounts of text or replacement figures.

Inserts an icon linking to the attached file in the appropriate pace in the text.

\section{How to use it}

- Click on the Attach File icon in the Annotations section.

- Click on the proof to where you'd like the attached file to be linked.

- Select the file to be attached from your computer or network.

- Select the colour and type of icon that will appear in the proof. Click OK.

\section{E N D}

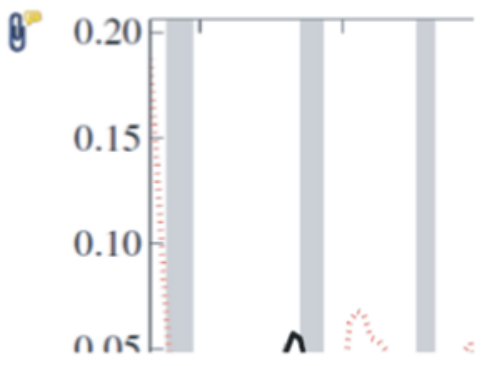

6. Add stamp Tool - for approving a proof if no corrections are required.

- Inserts a selected stamp onto an appropriate place in the proof.

\section{How to use it}

- Click on the Add stamp icon in the Annotations section.

- Select the stamp you want to use. (The Approved stamp is usually available directly in the menu that appears).

- Click on the proof where you'd like the stamp to appear. (Where a proof is to be approved as it is, this would normally be on the first page).

tr the Dusiness cycie, starung with the on perfect competition, constant ret hy otaki (1987), has introduced produc general equilibrium models with nomin:

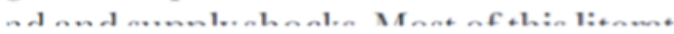

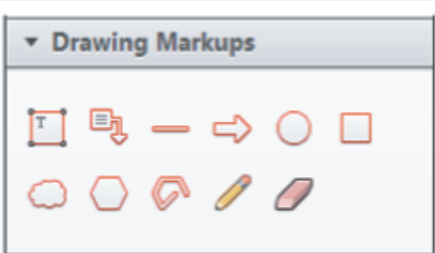

\section{How to use it}

- Click on one of the shapes in the Drawing Markups section.

- Click on the proof at the relevant point and draw the selected shape with the cursor.

- To add a comment to the drawn shape, move the cursor over the shape until an arrowhead appears.

- Double click on the shape and type any text in the red box that appears.
7. Drawing Markups Tools - for drawing shapes, lines and freeform annotations on proofs and commenting on these marks.

Allows shapes, lines and freeform annotations to be drawn on proofs and for comment to be made on these marks..

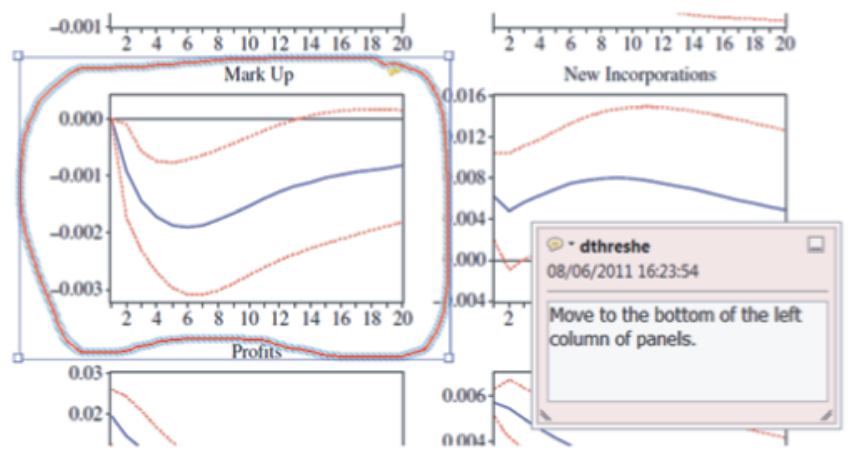

For further information on how to annotate proofs, click on the Help menu to reveal a list of further options:

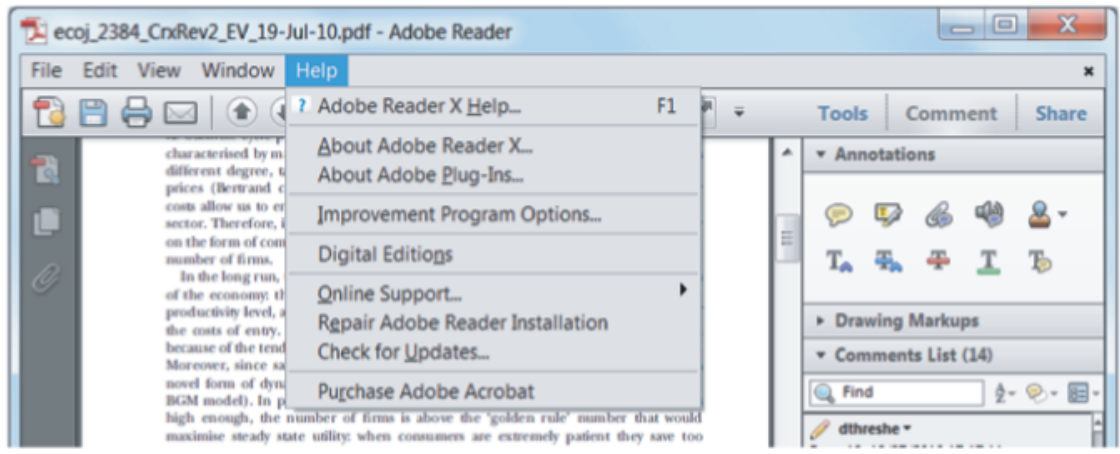

